\title{
Silymarin in Dermatology: A Brief Review
}

\author{
Shadi Mehraban ${ }^{1}$ and Amir Feily ${ }^{2^{*}}$
}

${ }^{1}$ Medical Student, Jahrom university of Medical Sciences, Jahrom, Iran

${ }^{2}$ Department of Dermatology, Jahrom University of Medical Sciences, Jahrom, Iran

*Corresponding author: Amir Feily, Department of Dermatology, Honari Clinic, Motahari Street, Jahrom, Iran, Tel: 00989177204638; E-mail: dr.feily@yahoo.com

Rec date: Jul 21, 2014; Acc date: Aug 02, 2014; Pub date: Aug 04, 2014

Copyright: ( 2014 Mehraban S. This is an open-access article distributed under the terms of the Creative Commons Attribution License, which permits unrestricted use, distribution, and reproduction in any medium, provided the original author and source are credited.

\section{Abstract}

Background: Silymarin, a flavonoid with antioxidant activities and extracted from milk thistle (Silybum marianum), previously used for its liver protection activity has been recently tested for dermatologic disorders

Objectives: Our purpose was to summerize all the dermatologic oriented in vitro and in vivo experiments and clinical trials on silymarin.

Methods: A systematic review of the literature was conducted to investigate all the available data and summarize all the clinical trials, case reports and original articles on silymarin. Two major databases (PubMed and Google Scholar) were searched.

Results: We have gone over about 26 articles. Silymarin, has been shown to have anticarcinogenic effects against ultraviolet radiation which makes it an ideal agent for supplementing sunscreens protection. Silymarin has also been effective in overcoming rosacea, melasma, vitiligo and psoriasis.

Conclusions: Even though there are some promising results with silymarin in dermatologic conditions but its human efficacy is not sufficiently explored as yet.

\section{Keywords: Silymarin; Review; Skin}

\section{Introduction}

Silymarin is a flavonoid extracted from the seeds of milk thistle (Silybum marianum) or artichoke and is made up of three primary flavonolignans; silybin (silibinin), silydianin and silychristin [1-3]. Silibinin is the chief constituent of silymarin as it is the most active biological agent of the three; however, studies have revealed that silymarin and silibinin act quite the same as chemopreventive and biological agents with the slightest difference [3]. Silymarin has been used for liver protection for centuries [4]. Regarding the anti-oxidant and anti-inflammatory activities proposed for silymarin, it has recently been widely put to the test to be assessed as a photoprotective agent against the deleterious effects of the solar ultraviolet radiation which has been assumed to be the major cause of melanoma and nonmelanoma skin cancers via production of reactive oxygen species $[5,6]$. There are also studies which suggest that silymarin may be effective in prevention of prostate and breast cancers $[7,8]$. In this review article we aim to discuss all the dermatological features tested and proposed for silymarin.

\section{Silymarin and UV protection}

There are many studies regarding the photoprotection of silymarin in literature. In a study on epidermal cell it has been shown that the apoptosis and DNA damage caused by ultraviolet radiation was markedly decreased by silymarin via the nucleotide excision repair mechanism which makes silymarin an excellent option for prophylaxis of skin cancers [9]. Also, another investigation conducted by Meeran
SM et al. indicated the same results regarding the inhibitory effects of silymarin on photocarcinogenesis by means of downregulation of the immunosuppressive cytokine, interleukin-10, and upregulation of the immunostimulator cytokine, interleukin-12 [10]. Another study on mice demonstrated that skin sampling of the mice treated with silymarin either before or after UV exposure illustrated diminished infiltration of leukocytes especially, $\mathrm{CD} 11 \mathrm{~b}+$ and also decreased number of cells producing $\mathrm{H}_{2} \mathrm{O}_{2}$ and nitric oxide suggesting silymarin to be an anticarcinogenic and anti-inflammatory agent $[11,12]$. Vaid $\mathrm{M}$ et al. proved silymarin to be effective in inhibiting the immunosuppression caused by ultraviolet radiation by means of dendritic cells \& T cells [13].

\section{Anti-melanoma and skin cancer}

In a study on SENCAR mice, silymarin indicated high efficacy in preventing tumor advancement, i.e. tumor incidence, multiplicity \& volume, more profoundly evident in stage I tumors, which can be attributable to preventing 12-O-tetradecanoylphorbol 13-acetate (TPA) from giving rise to edema, hyperplasia, DNA synthesis and peroxidation [14]. In another study, Vaid $M$ et al. showed silymarin to be effective in preventing not only skin cancers but also melanoma cell migration via the B-catenin signaling pathway [15]. Anticancer effects of silymarin is through deactivating the tyrosine kinase signaling pathway and reducing the tyrosine phosphorylation mediated by the Epidermal Growth Factor Receptor (EGFR) and SHC (with no change in their protein levels) which leads to disturbance in the cell cycle progression, G1 arrest and therefore preventing malignant cells to grow [16]. In another study Katiyar et al. illustrated that treatment 
Page 2 of 3

with silymarin to be of benefit in preventing various stages of ultraviolet B-induced nonmelanoma skin cancer in mice, with its utmost effect in UVB-induced complete carcinogenesis, UVB-induced tumor promotion and UVB-induced tumor initiation, respectively [17]. Applying sunscreens containing silymarin as a component to the skin of mice showed promising results in inhibition of development of nonmelonamoa skin cancers via blocking the production of pyrimidine dimmers which are DNA lesions formed as a result of ultraviolet radiation exposure [18]. The 12-Otetradecanoylphorbol-13-acetate (TPA) induced epidermal activity of ornithine decarboxylase (ODC), a notorious tumor promoter, was evaluated in SENCAR mice following the administration of silymarin as a cancer chemopreventive agent which was substantially decreased in a dose- and time-dependent manner [2].

\section{Silymarin and Rosacea}

In a study on Forty-six patients affected by stage I-III rosacea Berardesca et al. demonstrated that combination therapy of silymarin and methylsulfonylmethane can be useful in the treatment of rosacea skin, especially in the rosacea subtype 1 erythemato-telangiectatic phase. It was effective on skin erythema, pruritus, papules and skin color [19].

\section{Silymarin and Melasma}

Silymarin was also beneficial in treating UVA-induced skin damage in a dose-dependent manner [20,21]. Moreover, treatment of melasma with silymarin indicated substantial improvement from the first week of therapy [22].

\section{Silymarin and Vitiligo}

Both combination therapy with trioxsalen and silymarin suspension and silymarin alone has been used in the treatment of vitiligo [23]. In another hypothetical paper, Feily and Namazi in 2011 demonstrated several mechanisms of silymarin in the treatment of vitiligo but it has not been yet studied and needs more attention [24].

\section{Silimaryn and Psorisis}

There are anecdotal reports of efficay of Silymarin in the treatment of psoriasis $[25,26]$.

\section{Discussion}

A systematic review of the literature was conducted to investigate all the available data and summarize all the clinical trials, case reports and original articles on silymarin. Two major databases (PubMed and Google Scholar) were searched. We have gone over about 26 articles. Silymarin, a flavonoid extracted from the seeds of milk thistle(Silybum marianum), used previously for liver protection and possibly effective in the prevention of breast and prostate cancers $[4,7,8]$, has been shown to have anticarcinogenic effects against ultraviolet radiation via different mechanisms, e.g. decreasing apoptosis and DNA damage, downregulation of the immunosuppressive cytokine, interleukin-10, and upregulation of the immunostimulator cytokine, interleukin-12 $[9,10]$, reducing infiltration of leukocytes especially, CD11b+ and also decreasing the number of cells producing $\mathrm{H}_{2} \mathrm{O}_{2}$ and nitric oxide, which makes it an ideal agent for supplementing sunscreens protection $[11,12]$. Silymarin has also been effective in prevention of skin cancers, rosacea, melasma. There is one hypothesis regarding the efficacy of silymarin on vitiligo and anecdotal reports in the treatment of psoriasis but they have not been yet studied and needs more attention. Even though there are some promising results with silymarin in dermatologic conditions but its human efficacy is not sufficiently explored as yet.

\section{References}

1. Katiyar SK (2005) Silymarin and skin cancer prevention: antiinflammatory, antioxidant and immunomodulatory effects (Review). See comment in PubMed Commons below Int J Oncol 26: 169-176.

2. Agarwal R, Katiyar SK, Lundgren DW, Mukhtar H (1994) Inhibitory effect of silymarin, an anti-hepatotoxic flavonoid, on 12-Otetradecanoylphorbol-13-acetate-induced epidermal ornithine decarboxylase activity and mRNA in SENCAR mice. Carcinogenesis 15: 1099-1103.

3. Vaid M, Katiyar SK (2010) Molecular mechanisms of inhibition of photocarcinogenesis by silymarin, a phytochemical from milk thistle (Silybum marianum L. Gaertn.) (Review). See comment in PubMed Commons below Int J Oncol 36: 1053-1060.

4. Dattner AM (2003) From medical herbalism to phytotherapy in dermatology: back to the future. See comment in PubMed Commons below Dermatol Ther 16: 106-113.

5. Nichols JA, Katiyar SK (2010) Skin photoprotection by natural polyphenols: anti-inflammatory, antioxidant and DNA repair mechanisms. See comment in PubMed Commons below Arch Dermatol Res 302: 71-83.

6. Afaq F, Adhami VM, Ahmad N, Mukhtar H (2002) Botanical antioxidants for chemoprevention of photocarcinogenesis. See comment in PubMed Commons below Front Biosci 7: d784-792.

7. Zi X, Grasso AW, Kung HJ, Agarwal R (1998) A flavonoid antioxidant, silymarin, inhibits activation of erbB1 signaling and induces cyclindependent kinase inhibitors, G1 arrest, and anticarcinogenic effects in human prostate carcinoma DU145 cells. Cancer Res 58: 1920-1929.

8. Zi X, Feyes DK, Agarwal R (1998) Anticarcinogenic effect of a flavonoid antioxidant, silymarin, in human breast cancer cells MDA-MB 468: induction of G1 arrest through an increase in Cip1/p21 concomitant with a decrease in kinase activity of cyclin-dependent kinases and associated cyclins. Clin Cancer Res 4: 1055-1064.

9. Katiyar SK, Mantena SK, Meeran SM (2011) Silymarin protects epidermal keratinocytes from ultraviolet radiation-induced apoptosis and DNA damage by nucleotide excision repair mechanism. See comment in PubMed Commons below PLoS One 6: e21410.

10. Meeran SM, Katiyar S, Elmets CA, Katiyar SK (2006) Silymarin inhibits UV radiation-induced immunosuppression through augmentation of interleukin-12 in mice. See comment in PubMed Commons below Mol Cancer Ther 5: 1660-1668.

11. Katiyar SK, Meleth S, Sharma SD (2008) Silymarin, a flavonoid from milk thistle (Silybum marianum L.), inhibits UV-induced oxidative stress through targeting infiltrating CD11b+ cells in mouse skin. See comment in PubMed Commons below Photochem Photobiol 84: 266-271.

12. Katiyar SK (2002) Treatment of silymarin, a plant flavonoid, prevents ultraviolet light-induced immune suppression and oxidative stress in mouse skin. See comment in PubMed Commons below Int J Oncol 21: 1213-1222.

13. Vaid M, Prasad R, Singh T, Elmets CA, Xu H, et al. (2013) Silymarin inhibits ultraviolet radiation-induced immune suppression through DNA repair-dependent activation of dendritic cells and stimulation of effector T cells. Biochem Pharmacol 85: 1066-1076.

14. Lahiri-Chatterjee M, Katiyar SK, Mohan RR, Agarwal R (1999) A flavonoid antioxidant, silymarin, affords exceptionally high protection against tumor promotion in the SENCAR mouse skin tumorigenesis model. Cancer Res 59: 622-632. 
Page 3 of 3

15. Vaid M, Prasad R, Sun Q, Katiyar SK (2011) Silymarin targets $\hat{\mathrm{I}}^{2}$-catenin signaling in blocking migration/invasion of human melanoma cells. See comment in PubMed Commons below PLoS One 6: e23000.

16. Ahmad N, Gali H, Javed S, Agarwal R (1998) Skin cancer chemopreventive effects of a flavonoid antioxidant silymarin are mediated via impairment of receptor tyrosine kinase signaling and perturbation in cell cycle progression. Biochem Biophys Res Commun 247: 294-301.

17. Katiyar SK, Korman NJ, Mukhtar H, Agarwal R (1997) Protective effects of silymarin against photocarcinogenesis in a mouse skin model. See comment in PubMed Commons below J Natl Cancer Inst 89: 556-566.

18. Chatterjee ML, Agarwal R, Mukhtar H (1996) Ultraviolet B radiationinduced DNA lesions in mouse epidermis: an assessment using a nove 32P-postlabelling technique. See comment in PubMed Commons below Biochem Biophys Res Commun 229: 590-595.

19. Berardesca E, Cameli N, Cavallotti C, Levy JL, Piérard GE, et al. (2008) Combined effects of silymarin and methylsulfonylmethane in the management of rosacea: clinical and instrumental evaluation. See comment in PubMed Commons below J Cosmet Dermatol 7: 8-14

20. Svobodová $\mathrm{A}, \mathrm{Zdarilová} \mathrm{A}$, Malisková J, Mikulková $\mathrm{H}$, Walterová $\mathrm{D}$, et al. (2007) Attenuation of UVA-induced damage to human keratinocytes by silymarin. See comment in PubMed Commons below J Dermatol Sci 46: 21-30.

21. Svobodová A, Zdarilová A, Walterová D, Vostálová J (2007) Flavonolignans from Silybum marianum moderate UVA-induced oxidative damage to $\mathrm{HaCaT}$ keratinocytes. See comment in PubMed Commons below J Dermatol Sci 48: 213-224.

22. Altaei T (2012) The treatment of melasma by silymarin cream. See comment in PubMed Commons below BMC Dermatol 12: 18.

23. Sehgal VN (2009) Role of tacrolimus (FK506) $0.1 \%$ ointment WW in vitiligo in children and imperatives of combine therapy with Trioxsalen and Silymarin suspension in progressive vitiligo. See comment in PubMed Commons below J Eur Acad Dermatol Venereol 23: 1218-1219.

24. Feily A, Namazi MR (2011) Silymarin as a potential novel addition to the limited anti-vitiligo weaponry: an untested hypothesis. See comment in PubMed Commons below Int J Clin Pharmacol Ther 49: 467-468.

25. Fiebrich F, Koch H (1979) Silymarin, an inhibitor of lipoxygenase. See comment in PubMed Commons below Experientia 35: 1548-1560.

26. Koch HP, Bachner J, Löffler E (1985) Silymarin: potent inhibitor of cyclic AMP phosphodiesterase. See comment in PubMed Commons below Methods Find Exp Clin Pharmacol 7: 409-413. 